publishing practice and of research funding unscrupulous careerists will continue to prosper.

DONALD EVANS

Department of Philosophy, University College, Cardiff.

\section{Doctors' Dilemmas: Medical Ethics and Contemporary Science}

\author{
Melanie Phillips and John Dawson, \\ Brighton, ix and 230 pages, \\ $£ 8.95$ paperback, $£ 22.00$ hardback, \\ Harvester Press, 1985
}

This book, written by a journalist and a doctor in collaboration, has two main aims. One is to survey five main problem areas in medical ethics - life and death issues (whether killing and letting die are morally equivalent and whether there is always an obligation to save life); the ethics of research and experimentation; the relations between doctors and the State, especially in prisons; the obligation to tell patients the truth; and the problem of the allocation of limited resources. The book provides a useful survey of the moral problems in these areas; and we should be particularly grateful for the coverage of the last three, which have not received as much attention as other parts of medical ethics. There are also many sensible comments en route, such as the discussion of the role of moral philosophy on pp 17-19.

The second aim is to argue for a mechanism whereby the consensus of society on these issues can be obtained and applied, in order that an appropriate decision may be reached: it is accepted that this process would involve compromising between various points of view and also will be on-going, since societies do not settle moral questions once and for all. This makes an important point: there is a need for patients, and for society at large, to become more involved in medical decision-making, particularly, perhaps, with regard to general principles. Unfortunately, the point is made in an exaggerated way, and the arguments used are, one has to say, slovenly. The slovenliness appears in three areas.

First, the authors' understanding of the people they criticise is poor. On p 5 a passage from the BMA handbook, Medical Ethics, 1970, is called 'paternalistic, insular complacency'; but it is not about relations between doctors and patients at all, but about relations between doctors themselves.
John Harris does not 'argue inexorably for infanticide' ( $p$ 38), but argues that infanticide and withholding nourishment are morally equivalent: he inclines to the view that both are wrong. The judge in the Arthur case (p 44), in directing the jury that it was lawful to withhold nourishment if, among other conditions, the child was rejected by its parents, was not implying that the child had no rights, but merely that what was in its best interests depended in part on the willingness of the parents to care for it. And - a final example - the authors' further comments on the judge's directions seem to ignore the difference between necessary and sufficient conditions.

Secondly, there is a cavalier attitude to rational argument. Positions are taken up not because of their merits but because they yield the conclusions the authors want. Thus in chapter 2 they uphold the moral distinction between killing and letting die, but in chapter 5 reject the much more plausible distinction between lying and withholding information: this may be consistent, but reasons need to be given. Most seriously, they opt for abandoning logic altogether when it leads to conclusions they dislike, such as the conclusion that killing and letting die are morally equivalent. This is both disreputable and unnecessary, as is shown by the points quoted from Lorber on p 38: if correct, Lorber's arguments would show precisely that the consequences of infanticide would be worse than those of withholding nourishment, and therefore that the two are not equivalent. (What they do not show is that withholding nourishment is right).

Thirdly, there is a stigmatisation of ways other than consensus of deciding moral issues. Leaving issues to individual doctors is not 'moral anarchy': it is decision by individual conscience. A judge does not act in a 'moral vacuum' merely because he does not use, or does not know, the current moral consensus: he acts morally, using tradition, conscience or the law itself as his guide. Consensus is not the only way of making moral decisions, nor always the appropriate one. Thus, some areas of medical ethics involve the rights of individual patients and doctors, which should be upheld whether society likes it or not. Others involve detailed knowledge of individual circumstances, and are therefore best left to the discretion of the patients and/or doctors involved. Others involve so much technical knowledge that the medical profession itself is the best judge.
Certainly on some issues the view of society as a whole - if it has one and if it can be determined - would be extremely valuable; but only on some, not all. Moreover, there is no guarantee that the kind of body proposed on $p$ 190 , including 'doctors, scientists, other health professionals, theologians and others' (one hopes the 'others' include representatives of the old, the poor and the ill!), would in fact reach conclusions in line with those of society as a whole, useful though the deliberations of such a committee would be. In short, the authors do not make out their case, but we should be grateful to them for discussing the problems and putting forward their view, which deserves serious consideration.

A H LESSER Department of Philosophy, University of Manchester

\section{Soviet Psychiatric Abuse: the Shadow Over World Psychiatry}

Sidney Bloch and Peter Reddaway, 288 pages, London, $£ 10.95$, Victor Gollancz, 1984.

Bloch and Reddaway are probably the two most persistent and thorough campaigners against the abuse of psychiatry in the Soviet Union. They first brought Soviet practices to our attention in Russia's Political Hospitals (1977), an excellent account containing a large number of well documented case histories. Their new book is in the same fine tradition as the original. It provides an excellent contemporary historical assessment of the response to psychiatric abuse in the Soviet Union. What impresses is the objectiveness and detail of reporting. The authors examine the importance of the Sixth World Psychiatric Association (WPA) Congress in Honolulu in 1977, where there was a narrow vote to condemn Soviet psychiatric abuse. The WPA established a 'Committee to Review the Abuse of Psychiatry for Political Reasons'.

Bloch and Reddaway comprehensively document all of the major activities againt Soviet psychiatry that took place in the West between the Honolulu and subsequent Vienna World Psychiatric Congress. Much of 
the activity was undertaken by the Royal College of Psychiatrists and the American Psychiatric Association which both set up special committees to liaise with the WPA review committee.

Perhaps of even greater interest is the authors' account of resistance in the Soviet Union, and their comment on whether internal and/or external pressure actually changed Soviet practices. The figures are complex, but it is fair to conclude that there has been a drop in psychiatric internment in the USSR and that it might be causally related to outside pressure.

It is today almost easy to see Soviet abuses of psychiatry as self-evident, while being less than vigorous in critically analysing Western abuses. It is of interest that much of the criticism of Soviet psychiatry has come from her two great ideological adversaries - the United States and Britain. What I like about Bloch and Reddaway is that they are prepared to delve into this potential cultural bias. In a lengthy first chapter, they examine the question - 'Political abuse: what is it?' An analysis of Soviet law shows some of the shortcomings of that system. Criminal confinement to a 'special hospital' requires psychiatric evidence and a finding of incompetency. Release from a special hospital is based upon a prediction of dangerousness, and the executive branch of government in the Soviet Union is also involved.

This is not very different from Britain, and it is worth pointing out that our system, until the Mental Health Act 1983, required the Home Secretary's consent to discharge restricted mental patients. The European Court of Human Rights found this to be a violation of Article 5(4) of the Human Rights Convention in 1982. The most obvious flaw in the Soviet facade of justice is the fact that the courts will almost never allow the defence to introduce their own psychiatric evidence, particularly if a report from the prestigious Serbsky Institutes is offered by the State.

Bloch and Reddaway are perhaps too complacent when they point to the vagueness in the language used by Soviet psychiatrists, while ignoring the vagueness in our own nomenclature. The Soviets use such terms as 'psychomotor excitement with a tendency towards aggressive actions'. But our own definition of 'psychopathic disorder' is vague and somewhat tautological: it implies a disorder originating from anti-social behaviour, while purporting to explain the behaviour by the presence of the disorder. The British term was itself criticised by the World Health Organisation in 1978.

It is just conceivable to understand (but not forgive) Soviet psychiatrists' readiness to use their skills in serving the State. But it is the State itself which is the root cause of the problem. The Soviet criminal system extends the definition of danger radically to cover 'political' as well as customary physical forms of 'danger'.

Bloch and Reddaway's book firmly places the issue of Soviet psychiatric abuse back on the world stage. But the Soviet Union is not alone. There have been well documented cases of shameful conditions in Japanese psychiatric institutions causing death and despair (1). Much also needs to be done to expose the deliberate use of psychiatry as a measure of repression against black protesters in South Atrica. On a smaller scale should we ask why medical pressure prevented a new Mental Health Act being signed by the President in Eire despite its passage in both houses of the Dail; or why America can 'dump' psychiatric patients into the street; or why British special hospitals don't have any independent complaints system for patients?

If Bloch and Reddaway's book is to have some purpose it should be to spur international human rights groups into action. I was a member of the Committee of Experts which met in Siracusa (Sicily) in 1981 to draft a United Nations Convention on the Rights of Mentally Disordered Persons. Yet, partly through Soviet filibuster, the Convention has still not seen the light of day, and is unlikely to for perhaps a decade to come. How many more abuses of psychiatry worldwide must occur before national and international human rights groups take a firm initiative?

\section{Reference}

(1) Andersson A. Japanese psychiatry: mounting pressure for reform. Nature 1985; 316:571. Guardian 1985 Aug 14. Totsuka E, Mitsuishi T, Kitamura Y. Mental health and human rights: illegal detention in Japan. In: Carmi A. Schneider S, Hefez A, eds. Psychiatry, law and ethics. Berlin: Springer-Verlag, 1986.

LARRY GOSTIN Senior Fellow in Health Law, Harvard University School of Public Health, Boston, Massachusetts.

\section{To Do No Harm - DES and the Dilemmas of Modern Medicine}

Roberta J Apfel and Susan M Fisher, 199 pages, New Haven and London, $£ 13.95$, Yale University Press, 1984.

Sex hormones are fascinating and dangerous substances. Natural surges of the male hormone, testosterone, can make stags and bulls fighting mad, and in our own species testosterone no doubt makes its subtle contribution to football riots and world wars. The natural female hormone, oestrogen, is implicated in the development of cancer of the breast and uterus. Over 150 million women throughout the world now take synthetic oestrogens in the oral contracentive pill, though as far as breast cancer is concerned we still do not know whether these artificial hormones are safer or more dangerous than natural ones.

The first synthetic oestrogen, diethylstilboestrol (DES), was discovered in Britain in the 1940s, and was chemically very different from either the natural hormone or those nowo used in the Pill. It quickly became popular in the United States of America as a treatment for threatened miscarriage, but is now known to be valueless in this condition, and worse still, to be teratogenic. DES can cause genital malformations and even vaginal cancer in female fetuses - abnormalities which may not be discovered until the affected child is in her teens or early twenties. To Do No Harm looks at this sad story from a psychological viewpoint. Dr Apfel and Dr Fisher, both female American psychiatrists, first became interested in DES when affected young women consulted them for psychotherapy - ostensibly for reasons other than DES exposure. The authors realised that the psychological ramifications included guilty feelings in the mothers and a curious mechanism of denial among doctors. Castration anxieties, distortion of motherdaughter and doctor-patient relationships, and the effects on physicians' self-esteem provide a fertile jungle for psychological exploration.

To Do No Harm begins with a review of the history of DES, followed by a chapter setting it in the context of medical knowledge in the 1950s, a summary of its physical effects, and chapters dealing with the psychological effects on affected girls, on mothers and on doctors. The authors avoid 